Article

\title{
Use of $\mathrm{H}_{2} \mathrm{O}_{2}$ to Cause Oxidative Stress, the Catalase Issue
}

\author{
Céline Ransy, Clément Vaz, Anne Lombès $(\mathbb{D}$ and Frédéric Bouillaud * \\ Institut Cochin, Université de Paris, INSERM, CNRS, F-75014 Paris, France; celine.ransy@inserm.fr (C.R.); \\ clement.vaz@inserm.fr (C.V.); anne.lombes@free.fr (A.L.) \\ * Correspondence: frederic.bouillaud@inserm.fr
}

Received: 10 November 2020; Accepted: 28 November 2020; Published: 30 November 2020

\begin{abstract}
Addition of hydrogen peroxide $\left(\mathrm{H}_{2} \mathrm{O}_{2}\right)$ is a method commonly used to trigger cellular oxidative stress. However, the doses used (often hundreds of micromolar) are disproportionally high with regard to physiological oxygen concentration (low micromolar). In this study using polarographic measurement of oxygen concentration in cellular suspensions we show that $\mathrm{H}_{2} \mathrm{O}_{2}$ addition results in $\mathrm{O}_{2}$ release as expected from catalase reaction. This reaction is fast enough to, within seconds, decrease drastically $\mathrm{H}_{2} \mathrm{O}_{2}$ concentration and to annihilate it within a few minutes. Firstly, this is likely to explain why recording of oxidative damage requires the high concentrations found in the literature. Secondly, it illustrates the potency of intracellular antioxidant $\left(\mathrm{H}_{2} \mathrm{O}_{2}\right)$ defense. Thirdly, it complicates the interpretation of experiments as subsequent observations might result from high/transient $\mathrm{H}_{2} \mathrm{O}_{2}$ exposure and/or from the diverse possible consequences of the $\mathrm{O}_{2}$ release.
\end{abstract}

Keywords: reactive oxygen species; oxidative damage; DNA strand break; cellular respiration; aconitase; fumarase

\section{Introduction}

Exposure to hydrogen peroxide $\left(\mathrm{H}_{2} \mathrm{O}_{2}\right)$ is a widely used procedure to cause oxidative damage/stress in cellular models. The Fenton's reaction between $\mathrm{H}_{2} \mathrm{O}_{2}$ and $\mathrm{Fe}^{2+}$ ions generates the highly reactive $\mathrm{OH}$ radical and is thought to be the main mechanism for oxidative damage [1]. Then the question arises as to whether the conditions used are relevant to the mechanism underlying endogenous oxidative damage. Oxidative damage to cells is supposed to result primarily from oxygen using reactions within cells: cellular respiration accounts for most of the cellular oxygen consumption hence mitochondria are supposed to be oxidative stress generators. A quick survey of the literature reveals that the concentrations of $\mathrm{H}_{2} \mathrm{O}_{2}$ used to trigger oxidative damage appear disproportionately high to anyone used to dealing with cellular respiration for the following reasons: Dissociation of oxygen from hemoglobin starts below $50 \mu \mathrm{M}$ and interstitial concentration is in the $20 \mu \mathrm{M}$ range [2] hence even lower within cells. The affinity of mitochondria for oxygen is extremely high [3,4] and consequently mitochondria can exhaust all incoming oxygen with minimal decrease in their respiratory rate. This allows a sustained oxygen consumption flux while oxygen concentration is close to zero [5]. This points to the distinction to be made between concentrations and fluxes. Several questions arise with regard to this $\mathrm{H}_{2} \mathrm{O}_{2}$ model of oxidative damage: (1) Why are these high concentrations of $\mathrm{H}_{2} \mathrm{O}_{2}$ necessary to observe oxidative damage? (2) Are there other consequences than direct oxidative damage by $\mathrm{H}_{2} \mathrm{O}_{2}$ ? (3) Are the induced modifications relevant to physiology and to the redox balance associated with aerobic life?

The aim of the present report is to attract attention to the fact that direct application of $\mathrm{H}_{2} \mathrm{O}_{2}$ to cells results in the generation of oxygen $\left(\mathrm{O}_{2}\right)$ because of the presence of catalase [6-8]. This is not unexpected but seems generally overlooked and is likely relevant to the above first two questions. 
With regard to the third question, which lies well beyond the scope of the present article, two comments arise: (1) High concentration of $\mathrm{H}_{2} \mathrm{O}_{2}$ may be justified with the belief that they would increase the frequency of oxidative damages but would not alter their nature. (2) In addition to normal aerobic metabolism, local concentrations might be closer to the experimental values mentioned before in the inflammatory state where enzymatic reactions generate oxygen radicals with the aim to kill unwanted organisms/cells.

Actually, this report originates from our attempts to generate DNA strand breaks in mitochondrial DNA with hydrogen sulfide [9,10]. In our hands hydrogen sulfide could neither cause nuclear [11] nor mitochondrial DNA damage, while $\mathrm{H}_{2} \mathrm{O}_{2}$ as a positive control required the high micromolar concentrations found in the literature (Appendix A).

Lipids and proteins are other targets for oxidative stress. The enzyme aconitase contains an iron atom $\left(\mathrm{Fe}^{2+}\right)$ sensitive to oxidative stress [12]. Its mitochondrial isoform is part of the tricarboxylic acid cycle (Krebs cycle). In contrast, fumarase, whose mitochondrial isoform is also part of the Krebs cycle, is resistant to oxidative stress. Similar experimental procedures detect aconitase and fumarase activities allowing sequential monitoring of these two reactions in the same reaction medium. Therefore, the aconitase to fumarase ratio is a convenient index of the extent of oxidative damages/stress [12]. Examination of this ratio in cells exposed to $\mathrm{H}_{2} \mathrm{O}_{2}$ could not detect indication of intracellular oxidative damage to aconitase unless $\mathrm{H}_{2} \mathrm{O}_{2}$ approached the millimolar concentration.

\section{Results}

\subsection{Values for $\mathrm{H}_{2} \mathrm{O}_{2}$ Concentration in the Literature}

The PubMed database was searched with the keywords «Oxidative damage and Hydrogen Peroxide» and only publications in open access were considered. This request yielded 5147 publications. They were sorted according to best match. The first 201 were scrutinized for $\mathrm{H}_{2} \mathrm{O}_{2}$ treatment with concentration values, yielding 112 publications, whose PMID identifiers are listed in Appendix B. Different experimental profiles had to be considered: 46 publications used a single $\mathrm{H}_{2} \mathrm{O}_{2}$ concentration value, 36 publications presented a dose response curve leading to the choice of a single concentration used throughout the rest of the study (this concentration was considered here), and 30 publications used a set of increasing concentrations with no privileged concentration leading us to consider the mean value between minimal and maximal concentrations. Then the repartition of the $\mathrm{H}_{2} \mathrm{O}_{2}$ concentrations used was as follow: $<10 \mu \mathrm{M} 4$ publications, 10-99 $\mu \mathrm{M} 14$ publications, $100-500 \mu \mathrm{M} 55$ publications, 501-1000 $\mu \mathrm{M} 13$ publications, and $>1000 \mu \mathrm{M} 26$ publications. The concentrations of $\mathrm{H}_{2} \mathrm{O}_{2}$ used to generate oxidative damage in cellular models are therefore in the high micromolar range with $84 \%$ above $100 \mu \mathrm{M}$. Notably the $100-500 \mu \mathrm{M}$ range was used in half of the publications.

\subsection{A Proportionate Increase in Dioxygen Follows High Micromolar $\mathrm{H}_{2} \mathrm{O}_{2}$ Addition}

Our initial aim was to evaluate mitochondrial DNA strand break in conditions of induction of mitochondrial sulfide oxidation in wild type chinese hamster ovary $(\mathrm{CHO})$ cells or in cells with overexpressed human sulfide quinone reductase [13]. We used the O2k oxygraph, which allows simultaneous measurement in two identical chambers (Figure 1). It showed that addition of high (hundreds) micromolar $\mathrm{H}_{2} \mathrm{O}_{2}$ resulted in an immediate release of molecular oxygen apparently proportionate to the $\mathrm{H}_{2} \mathrm{O}_{2}$ input, and $500 \mu \mathrm{M} \mathrm{H}_{2} \mathrm{O}_{2}$ led to oxygen concentrations above $250 \mu \mathrm{M}$, hence higher than that resulting from air saturation of the medium (approx. $200 \mu \mathrm{M}$ at $37^{\circ} \mathrm{C}$ ). However, with $25 \mu \mathrm{M} \mathrm{H}_{2} \mathrm{O}_{2}$ the oxygen release was hardly detected.

We hypothesized that catalase enzymatic activity $\left(\mathrm{H}_{2} \mathrm{O}_{2} \mathrm{H}_{2} \mathrm{O}+\frac{1}{2} \mathrm{O}_{2}\right)$ underlay the observed phenomenon. The reaction equation predicts that the oxygen concentration increase would equal half the concentration of $\mathrm{H}_{2} \mathrm{O}_{2}$ added, hence $12.5,50$, and $250 \mu \mathrm{M}$ in the examples shown in Figure 1 . Figure 2 shows the percentage of this theoretical oxygen increase that was actually measured in the experiments shown in Figure 1. More than $80 \%$ of predicted oxygen was recovered with $500 \mu \mathrm{M} \mathrm{H}_{2} \mathrm{O}_{2}$, 
roughly $50 \%$ with $100 \mu \mathrm{M}$, and this percentage dropped below $10 \%$ with $25 \mu \mathrm{M} \mathrm{H}_{2} \mathrm{O}_{2}$, at which the slow linear increase in the long term (120 s and more) is rather explained by small experimental differences exaggerated by the conversion in $\%$ of absolute values differing by two orders of magnitude. When the difference between two simultaneous experiments shown in Figure 1 was considered (empty circles in Figure 3), the percentage of $\mathrm{O}_{2}$ recovery was higher and reached $100 \%$ when the difference between $500 \mu \mathrm{M}$ and $100 \mu \mathrm{M}$ traces (hence $400 \mu \mathrm{M} \mathrm{H}_{2} \mathrm{O}_{2}$ ) was considered.
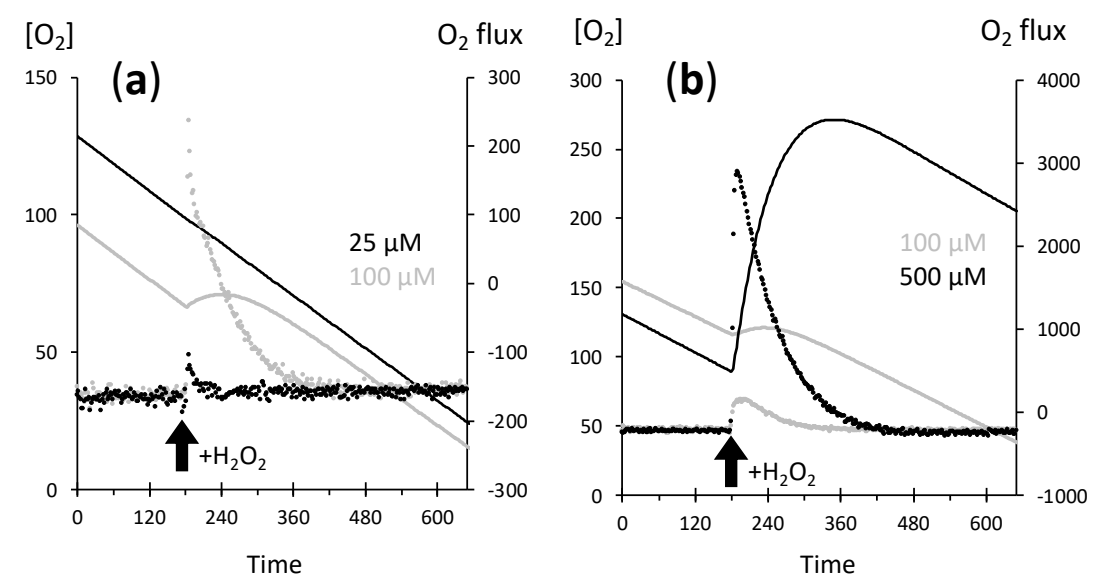

Figure 1. $\mathrm{O}_{2}$ release upon $\mathrm{H}_{2} \mathrm{O}_{2}$ addition. Chinese hamster ovary $(\mathrm{CHO})$ cells suspension at approx. $2 \times 10^{6}$ cells $/ \mathrm{mL} ; X$ axis $=$ time in seconds; left $Y$ axis $=$ recorded oxygen concentration expressed in $\mu \mathrm{M}$ (lines); right $\mathrm{Y}$ axis = oxygen flux rate in pmol/(s.mL) calculated over a two second interval (dots); and thick upward black arrow $=\mathrm{H}_{2} \mathrm{O}_{2}$ addition performed at time $180 \mathrm{~s}$. The stable negative value of oxygen rate before $\mathrm{H}_{2} \mathrm{O}_{2}$ addition is the oxygen consumption due to cellular respiration. Different $\mathrm{H}_{2} \mathrm{O}_{2}$ additions are represented: (a) $25 \mu \mathrm{M}$ (black symbols) or $100 \mu \mathrm{M}$ (grey symbols) $\mathrm{H}_{2} \mathrm{O}_{2}$ in the cellular suspension, (b) $500 \mu \mathrm{M}$ (black symbols) or $100 \mu \mathrm{M}$ (grey symbols) $\mathrm{H}_{2} \mathrm{O}_{2}$ in the cellular suspension.

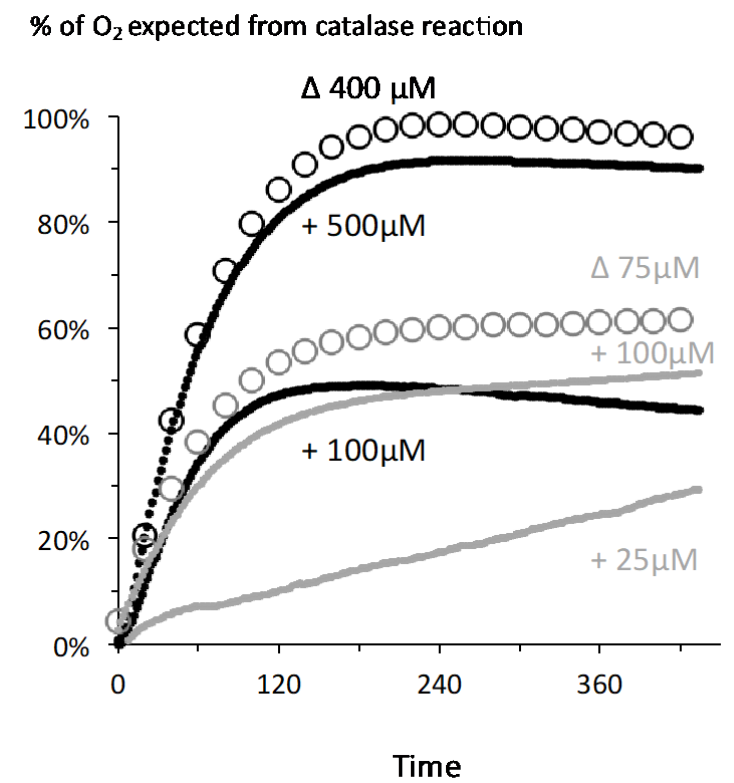

Figure 2. Increase in oxygen content in the medium compared to a full catalase reaction: $X$ axis $=$ time in seconds with addition of $\mathrm{H}_{2} \mathrm{O}_{2}$ considered as zero time; $Y$ axis = oxygen release expressed as percentage of the amount expected from a $100 \%$ yield for the catalase reaction $\left(\mathrm{O}_{2}=\frac{1}{2} \mathrm{H}_{2} \mathrm{O}_{2}\right)$. The two experiments presented in Figure $2 \mathrm{a}$ are in black symbols $\left(+100\right.$ and $\left.+500 \mu \mathrm{M} \mathrm{H}_{2} \mathrm{O}_{2}\right)$ while those presented in Figure $2 \mathrm{~b}$ are in grey $(+25 \mu \mathrm{M}$ and $+100 \mu \mathrm{M})$. Empty symbols represent results obtained when subtracting the oxygen release in the two concomitant chambers, i.e., either $100-25=75 \mu \mathrm{M}$ $\mathrm{H}_{2} \mathrm{O}_{2}$ or $500-100=400 \mu \mathrm{M}$, with one data point out of ten shown for the sake of clarity. 


\section{Maximal increase in $\mathrm{O}_{2}(\mu \mathrm{M})$}

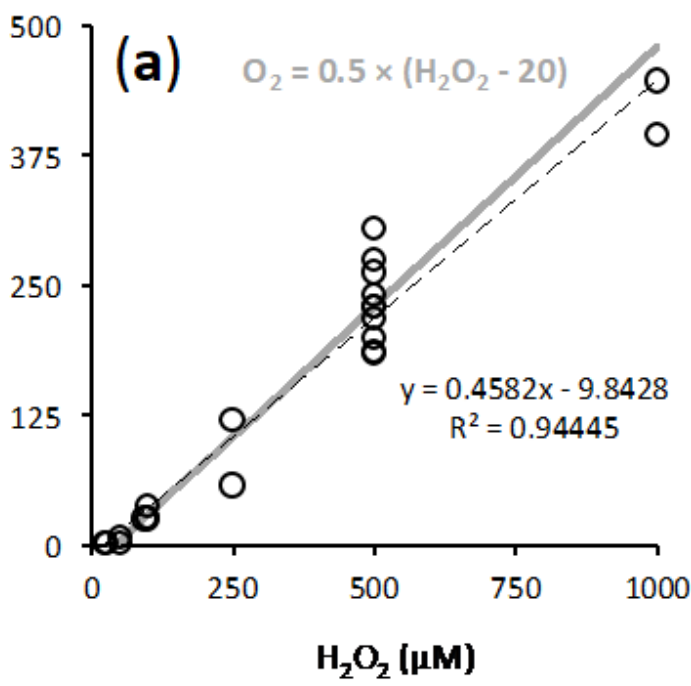

\section{Fraction of expected $\mathrm{O}_{2}$}

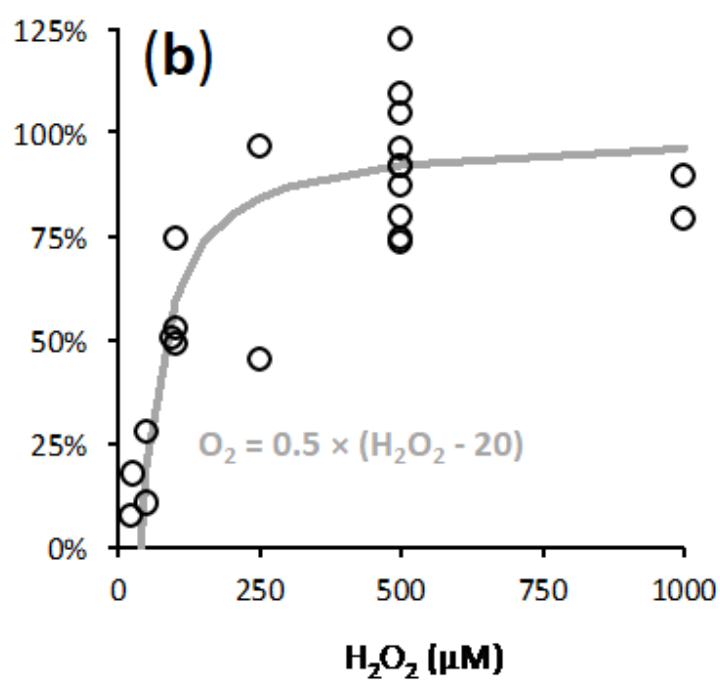

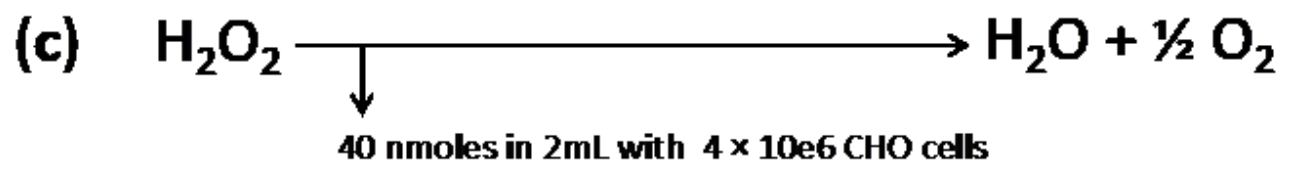

Figure 3. Recapitulation of experimental data led to a model for the reaction between $\mathrm{H}_{2} \mathrm{O}_{2}$ and $\mathrm{CHO}$ cells. $\mathrm{CHO}$ cells suspension ranged from 1.5 to $2.2 \times 10^{6} / \mathrm{mL}$. (a) $\mathrm{X}$ axis $=$ final $\mathrm{H}_{2} \mathrm{O}_{2}$ concentration in the medium, $Y$ axis = maximal observed increase in $\mathrm{O}_{2}$ (see Figure 2 for an example); dotted black line $=$ linear fitting according to the equation shown in grey (with values in $\mu \mathrm{M}$ ) in the panel upper part; grey lines = released oxygen given by the predicted equation of the model. (b) Expression of these $\mathrm{O}_{2}$ increases as percentage of the value expected from full engagement into catalase reaction, same $\mathrm{X}$ axis and symbols as in panel a. (c) Resulting model: upon $\mathrm{H}_{2} \mathrm{O}_{2}$ addition, 40 nanomoles $\mathrm{H}_{2} \mathrm{O}_{2}$ are immediately engaged in reactions not leading to $\mathrm{O}_{2}$ release; the rest of $\mathrm{H}_{2} \mathrm{O}_{2}$ is subjected to catalase action.

Putting together the results of all the experiments made with $\mathrm{H}_{2} \mathrm{O}_{2}$ additions in the 25-500 $\mu \mathrm{M}$ range and with $\mathrm{CHO}$ cells suspensions close to $2 \times 10 \mathrm{e} 6 \mathrm{cells} / \mathrm{mL}$ suggested a simple model (Figure 3 ). In that model two reactions took place: an immediate titration of a part of $\mathrm{H}_{2} \mathrm{O}_{2}$ and catalase reaction on the rest of $\mathrm{H}_{2} \mathrm{O}_{2}$. With the lowest $\mathrm{H}_{2} \mathrm{O}_{2}$ concentration $(25 \mu \mathrm{M})$ the immediate titration checked almost $100 \%$ of the $\mathrm{H}_{2} \mathrm{O}_{2}$ and little was made available to catalase (Figures 1 and 2).

Analysis of a range of cell concentrations strengthened the proposed role of cellular catalase (Figure 4). With increasing cell concentration, the lag time between $\mathrm{H}_{2} \mathrm{O}_{2}$ addition and maximal $\mathrm{O}_{2}$ release decreased (Figure 4a). A single experiment with medium alone led to a low rate of $\mathrm{O}_{2}$ release that reached a peak of $27 \mu \mathrm{M}$, hence $11 \%$ of the value explained by a catalase like reaction, after $1518 \mathrm{~s}$ (not shown on Figure 5). Altogether, this meant that the more cells, the faster the catalase reaction.

However, when the yield of the catalase reaction was considered it declined when lower amounts of cells were used. Time needed for completion of catalase reaction was then likely to be the determinant factor. To a significant extent experimental limitation could explain this because the determination of time and extent of the maximal $\mathrm{O}_{2}$ release became increasingly inaccurate when it took a long time. Another proposal would be that in addition to fast titration (see above) other slower reactions, which could involve components of the culture medium or renewal of $\mathrm{H}_{2} \mathrm{O}_{2}$ quenchers, contributed to $\mathrm{H}_{2} \mathrm{O}_{2}$ elimination. 


\section{Seconds to 02 max}

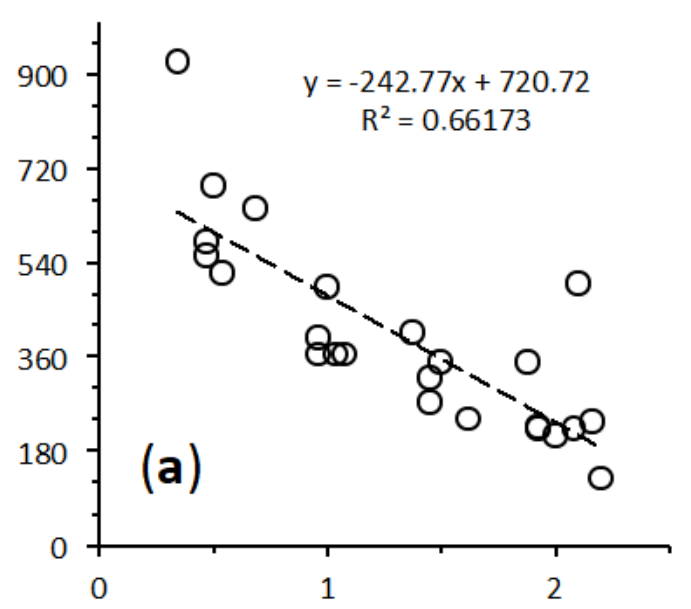

CHO cells $\left(10^{\mathrm{e}} 6 / \mathrm{ml}\right)$
Maximal increase in $\mathrm{O}_{2}(\mu \mathrm{M})$

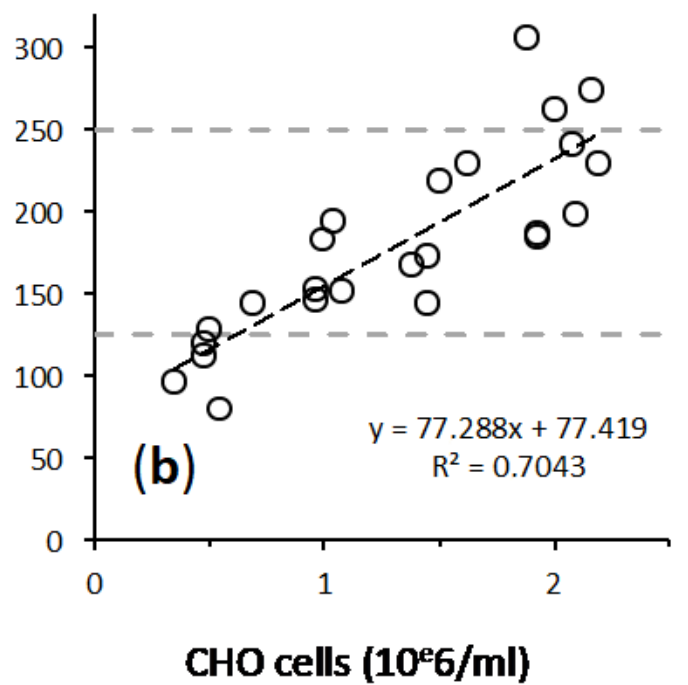

Figure 4. Influence of cell density on $\mathrm{O}_{2}$ release. $\mathrm{X}$ axis = concentration of $\mathrm{CHO}$ cells exposed to a single addition of $500 \mu \mathrm{M} \mathrm{H}_{2} \mathrm{O}_{2}$. (a) Time delay to reach the maximal $\mathrm{O}_{2}$ increase, inverse to the reaction rate. (b) $\mathrm{O}_{2}$ release in $\mu \mathrm{M}$ with dotted grey lines figuring the values corresponding to a $50 \%$ and $100 \%$ yield of $\mathrm{O}_{2}$ recovery from the catalase reaction $(125 \mu \mathrm{M}$ and $250 \mu \mathrm{M})$.

$\mathrm{O}_{2}$ release rate $\left(\mathrm{pmol} \mathrm{O}_{2} /\left(\mathrm{s} .10^{\mathrm{e}} 6\right.\right.$ cells $\left.)\right)$
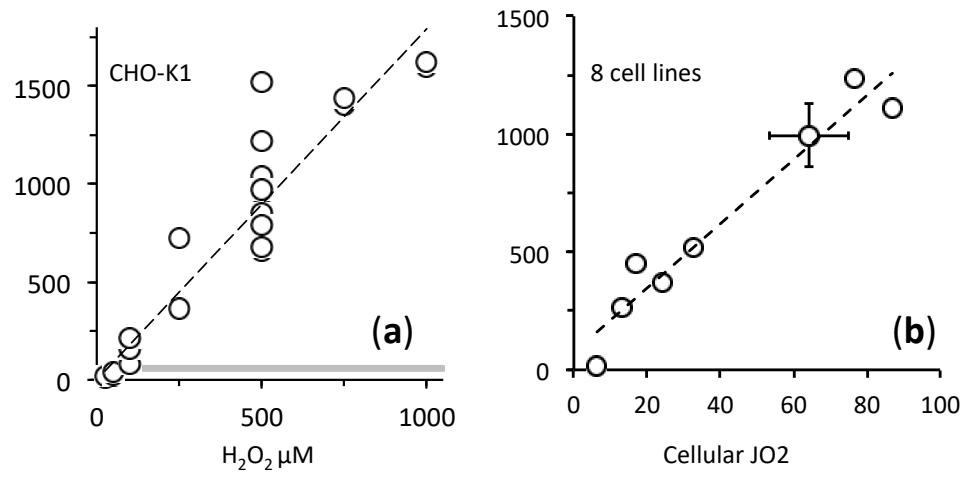

Figure 5. High initial rates of $\mathrm{O}_{2}$ reflect the catalytic efficacy of catalase reaction. $Y$ axis $=$ initial $\mathrm{O}_{2}$ release rate determined over 10 to $40 \mathrm{~s}$ after $\mathrm{H}_{2} \mathrm{O}_{2}$ injection; (a) $\mathrm{X}$ axis $=\mathrm{H}_{2} \mathrm{O}_{2}$ final concentration after injection; $\mathrm{CHO}-\mathrm{K} 1$ cells suspension were in the range 1.5 to $2.2 \times 10^{6}$ cells $/ \mathrm{mL}$; thick grey line $=\mathrm{CHO}-\mathrm{K} 1$ cellular oxygen consumption $\left(\approx 60 \mathrm{pmol} \mathrm{O}_{2} /\right.$ (second $\times 10^{6}$ cells) given for comparison's sake; dotted line = linear fitting, which suggested the absence of saturation up to $1 \mathrm{mM} \mathrm{H}_{2} \mathrm{O}_{2}$. (b) The catalase initial rate after $500 \mu \mathrm{M} \mathrm{H} 2 \mathrm{O} 2$ injection was determined with eight different cell lines. $X$ axis = endogenous cellular oxygen consumption rate (respiration) before the single $500 \mu \mathrm{M} \mathrm{H}_{2} \mathrm{O}_{2}$ addition. The different cell types are listed according to increasing $X$ values: human lymphoblasts (HPB-All, Jurkat, DND, Molt4), human immortalized skin fibroblast, $\mathrm{CHO}-\mathrm{K} 1 \pm \mathrm{SD}(n=21$ more data than in (a), cell density from 0.35 to $2 \times 10^{6}$ cells $/ \mathrm{mL}$ ), osteosarcoma 143B, and human neuroblastoma (SH-SY5Y). The dotted line represents linear fitting with values $Y=14 x+75$ with $R^{2}=0.94$.

\subsection{Fast Rates of Catalase Reaction}

Within three minutes, $2 \times 10^{6} \mathrm{CHO}$ cells neutralized $500 \mu \mathrm{M} \mathrm{H}_{2} \mathrm{O}_{2}$ (Figure 4a). This corresponds to an average rate while the initial rate was much faster (Figure 1). We estimated this initial rate and Figure 5a represents its dependence on $\mathrm{H}_{2} \mathrm{O}_{2}$ concentration with $\mathrm{CHO}$ cells. This initial rate of oxygen release remained proportionate to $\mathrm{H}_{2} \mathrm{O}_{2}$ concentration in the range $0-1000 \mu \mathrm{M}$ with no 
saturation. The oxygen release rate could largely outperform the cellular oxygen consumption rate (cellular respiration) with rates that are more than one order of magnitude higher in the opposite direction (Figure 5a). This fits with the very high turnover rate of the catalase catalytic cycle [6] as a consequence while minutes were needed to reach the maximal increase in $\mathrm{O}_{2}$ (Figure 4a), hence to exhaust all $\mathrm{H}_{2} \mathrm{O}_{2}$ in the external medium the $\mathrm{H}_{2} \mathrm{O}_{2}$ concentration decreased sharply within seconds after being in contact with cells.

We observed comparable rates for this catalase reaction in eight cell lines. Interestingly, the $\mathrm{O}_{2}$ release rate (catalase reaction) apparently correlated with the endogenous respiration rate, i.e., the cellular oxidative metabolism (Figure $5 b$ ).

\subsection{Cellular Respiration and Aconitase Activity Resistant to $\mathrm{H}_{2} \mathrm{O}_{2}$ in the High Micromolar Range}

We evaluated intracellular oxidative stress using the aconitase to fumarase ratio, which is considered a sensitive index [12]. Furthermore, we discriminated the cytosolic enzymes, revealed after mild digitonin treatment of the cells, from the mitochondrial enzymes, requiring drastic disruption of the mitochondrial inner membrane using Triton X100 (Figure 6). Increasing concentrations of $\mathrm{H}_{2} \mathrm{O}_{2}$ up to $500 \mu \mathrm{M}$ did not alter the aconitase to fumarase ratio, either in cytosol or in mitochondria (Figure 6a). One experiment with $\mathrm{H}_{2} \mathrm{O}_{2}$ concentration raised up to $1 \mathrm{mM}$ induced a detectable decrease in cytosolic aconitase activity that remained partial for the mitochondrial enzyme (Figure 6b).

(a)

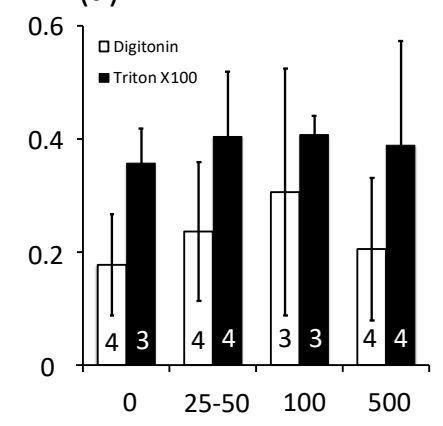

(b)

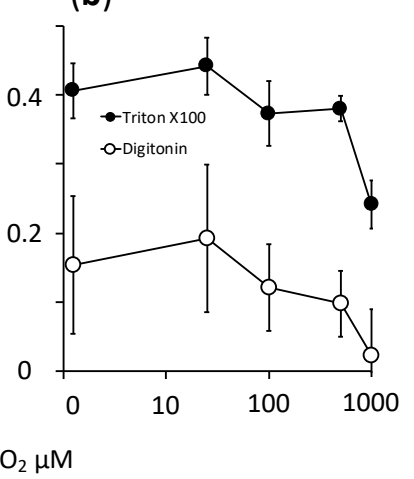

Figure 6. Evaluation of cellular oxidative stress using the aconitase to fumarase ratio in $\mathrm{CHO}$ cells exposed to $\mathrm{H}_{2} \mathrm{O}_{2}$. $Y$ axis = aconitase to fumarase ratio; $X$ axis $=\mathrm{H}_{2} \mathrm{O}_{2}$ concentration. (a) Empty bars = values observed in cells treated with digitonin (cytosolic activities); filled bars = values observed in cells treated with Triton X100 (both cytosolic and mitochondrial activities); values expressed as mean $\pm \mathrm{SD}$; the number of independent experiments is indicated at the bottom of the histogram bars. (b) Single experiment with the concentration of $\mathrm{H}_{2} \mathrm{O}_{2}$ raised to $1 \mathrm{mM}$; values expressed as mean and SD of the wells observed in that experiment.

Evaluation of a potential impact of $\mathrm{H}_{2} \mathrm{O}_{2}$ impact on cellular oxygen consuming reactions was impossible in the short term after $\mathrm{H}_{2} \mathrm{O}_{2}$ addition because of the $\mathrm{O}_{2}$ release. However, with the rapid decline of $\mathrm{H}_{2} \mathrm{O}_{2}$ concentration, cellular oxygen consumption rate became detectable, gradually converging towards a new stable value. Comparison of that value with the value observed just before $\mathrm{H}_{2} \mathrm{O}_{2}$ addition, used as reference, did not show any change with $\mathrm{H}_{2} \mathrm{O}_{2}$ ranging from 0 to $750 \mu \mathrm{M}$ (Figures 7 and 8). This was true within the period considered, limited to $30-40 \mathrm{~min}$ after $\mathrm{H}_{2} \mathrm{O}_{2}$ addition. Respiration showed a mild increase $(>110 \%)$ with $1 \mathrm{mM} \mathrm{H}_{2} \mathrm{O}_{2}$, likely explained by the huge increase in $\mathrm{O}_{2}$ concentration up to three times the level for saturation with air (not shown). With the reservation that we could not distinguish between mitochondrial respiration and other oxygen consuming processes, this suggested that intense exposure to $\mathrm{H}_{2} \mathrm{O}_{2}$ and subsequently to oxygen did not result in fast and irreversible damage to any critical component necessary for normal cellular respiration. This was fully consistent with the resistance of mitochondrial aconitase to the exogenous $\mathrm{H}_{2} \mathrm{O}_{2}$. 


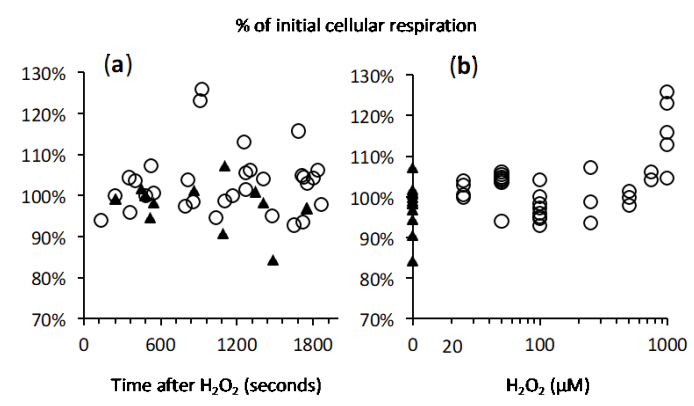

Figure 7. Absence of impact of $\mathrm{H}_{2} \mathrm{O}_{2}$ on $\mathrm{CHO}$ cells respiration. $Y$ axis = cellular oxygen consumption after $\mathrm{H}_{2} \mathrm{O}_{2}$ had been exhausted and expressed as percent of the initial rate (rate recorded just before $\mathrm{H}_{2} \mathrm{O}_{2}$ addition). (a) $\mathrm{X}$ axis = lag time between $\mathrm{H}_{2} \mathrm{O}_{2}$ addition and measurement oxygen consumption rate; black triangles refer to concomitant control experiments (without $\mathrm{H}_{2} \mathrm{O}_{2}$ ). (b) $\mathrm{X}$ axis = amount of $\mathrm{H}_{2} \mathrm{O}_{2}$ injected in the experiments represented in panel a.

Recovery of cellular respiration after $\mathrm{H}_{2} \mathrm{O}_{2}$

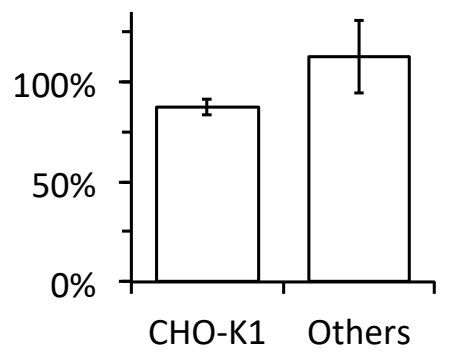

Figure 8. Absence of impact of $\mathrm{H}_{2} \mathrm{O}_{2}$ on the respiration is common to different cells. Oxygen consumption rate after $\mathrm{H}_{2} \mathrm{O}_{2}$ had been exhausted is expressed in \% of the reference rate for cells exposed to $500 \mu \mathrm{M} \mathrm{H}_{2} \mathrm{O}_{2}$; values expressed as mean \pm SD; CHO-K1: 21 preparations of CHO-K1 with cell density ranging from 0.35 to $2.08 \times 10^{\mathrm{e}} 6$ cells per mL. Others: 7 preparations of the cell lines used in Figure $5 b$ (one value per cell line cell and density ranging from 0.86 to $3 \times 10^{6}$ cells per $\mathrm{mL}$ ).

\section{Discussion}

The results presented here indicate that cells subjected to $\mathrm{H}_{2} \mathrm{O}_{2}$ exposure convert $\mathrm{H}_{2} \mathrm{O}_{2}$ into $\mathrm{O}_{2}$ within a few minutes. This makes the $\mathrm{H}_{2} \mathrm{O}_{2}$ exposure considerably shorter and less intense than expected. It may well explain why such high $\mathrm{H}_{2} \mathrm{O}_{2}$ concentrations were required to record detectable damages. The conversion of hundreds of micromolar $\mathrm{H}_{2} \mathrm{O}_{2}$ into oxygen has the consequence of exposing cells to $\mathrm{O}_{2}$ concentrations higher than that resulting from equilibration of the aqueous medium with air, a concentration already way above physiological oxygen concentrations [2].

The oxidative damages taking place after $\mathrm{H}_{2} \mathrm{O}_{2}$ exposure are thought to result for a significant (largest) part from the hydroxyl radical liberated by Fenton's reaction. However, a surge in superoxide has been associated with exposure to $\mathrm{H}_{2} \mathrm{O}_{2}$ [14]. Superoxide results from $\mathrm{O}_{2}$ reduction with a single electron, and is converted into $\mathrm{H}_{2} \mathrm{O}_{2}$ by superoxide dismutase. Occurrence of the reverse reaction, with generation of superoxide from $\mathrm{H}_{2} \mathrm{O}_{2}$, is not immediately obvious and is expected to be an indirect consequence of $\mathrm{H}_{2} \mathrm{O}_{2}$ exposure [15]. Our experiments indicate that a large increase in oxygen concentration is expected to take place at the site of catalase action hence inside the cell. This rise in intracellular $\mathrm{O}_{2}$ would greatly increase the probability of its reduction by leakage of a single electron from cellular metabolism. It may therefore provide a direct explanation for the observed increase in cellular superoxide production.

In our experiments, the equilibration of concentrations was immediate because of the stirring of the cellular suspension necessary for the measurement of cellular oxygen consumption. Consequently, cellular catalase could access added $\mathrm{H}_{2} \mathrm{O}_{2}$ within a short time. However, in cells attached at the bottom of a well and surrounded by a still medium, $\mathrm{O}_{2}$ and $\mathrm{H}_{2} \mathrm{O}_{2}$ may have restricted diffusion leading to 
delayed access to catalase. $\mathrm{H}_{2} \mathrm{O}_{2}$ may then represent an additional oxygen reserve. Interestingly, the dose response curve showed a rather positive effect of $\mathrm{H}_{2} \mathrm{O}_{2}$ at low concentrations, before the deleterious effect took place/dominated [16]. Reactive oxygen species (ROS) signaling might explain this observation but the improvement of cellular bioenergetics by $\mathrm{H}_{2} \mathrm{O}_{2} /$ catalase mediated $\mathrm{O}_{2}$ supply to mitochondria may also deserve consideration.

At low concentrations of $\mathrm{H}_{2} \mathrm{O}_{2}$, a significant proportion escaped from catalase action (Figures 2 and 3). One could easily envision that $\mathrm{H}_{2} \mathrm{O}_{2}$ would first titrate all the molecules able to react quickly with it. They would represent a "sink for $\mathrm{H}_{2} \mathrm{O}_{2}$ ", which includes components of the medium as well as cellular antioxidant defenses. This sink shows highest affinity but limited size (40 nanomoles in our experimental settings). In contrast, catalase shows relatively low affinity but a large activity able to neutralize within a few minutes surrounding $\mathrm{H}_{2} \mathrm{O}_{2}$ concentrations approaching the millimolar range, hence a micromole of $\mathrm{H}_{2} \mathrm{O}_{2}$ in our settings.

Altogether these observations render the interpretation of $\mathrm{H}_{2} \mathrm{O}_{2}$ experiments far more complex than considering a sudden increase in the probability for Fenton's reaction to occur (Figure 9).

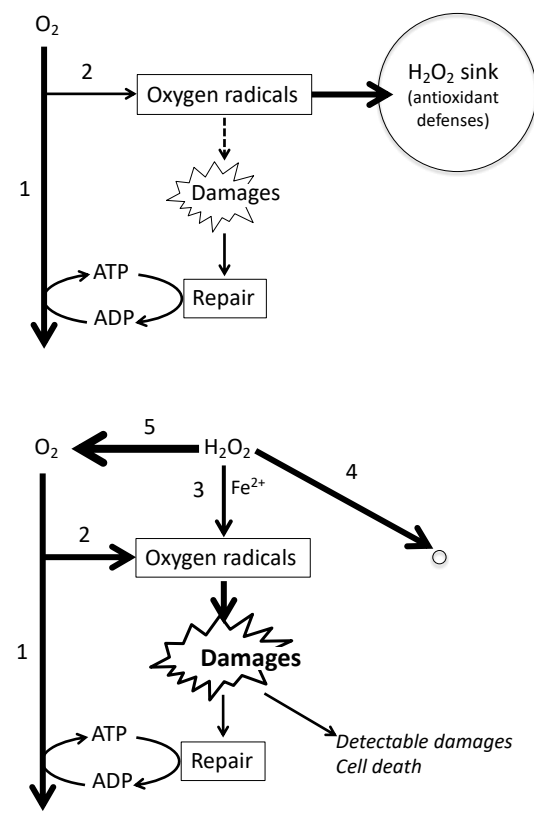

Figure 9. Scenario for $\mathrm{H}_{2} \mathrm{O}_{2}$ mediated oxidative damage. Top: normal cellular physiology, endogenous oxygen metabolism is essentially devoted to mitochondrial ATP generation (1). This and other oxygen using enzymes generate oxygen radicals (2) and a vast majority is eliminated by antioxidant defenses. Some oxidative damages (Damages) occur and cellular bioenergetics contributes to their reparation resulting in a steady state with no accumulation of oxidative lesions. Bottom: addition of $\mathrm{H}_{2} \mathrm{O}_{2}$ (high $\mu \mathrm{M}$ ) has three immediate consequences: it increases the probability of Fenton's reaction (3), $\mathrm{H}_{2} \mathrm{O}_{2}$ reacts within seconds with existing reactive molecules and annihilates the existing antioxidant defenses (4), and $\mathrm{H}_{2} \mathrm{O}_{2}$ concentration drops abruptly through action of cellular catalase. This increases greatly the intracellular $\mathrm{O}_{2}$ concentration (5) and hence endogenous oxygen radicals production (2). On one side oxygen radical generation is increased ( 2 and 3 ) and on the other side antioxidant defenses are invalidated (4). This is expected to generate oxidative damages at rates exceeding repair: they accumulate and become detectable and may result in cell death.

ROS release by mitochondria often leads to considering them as permanent cell threatening ROS generators, checked by antioxidant defenses. Decline of the latter would explain increase in oxidative damage. Mitochondrial superoxide dismutase (MnSOD) quickly converts mitochondrial superoxide, the essential mitochondrial ROS, into $\mathrm{H}_{2} \mathrm{O}_{2}$. Then, if the largest part of cellular oxidative damage has a mitochondrial origin, the mitochondrial exposure to $\mathrm{H}_{2} \mathrm{O}_{2}$ would be maximal as well as the possible damage. Indeed, coincidence between mitochondrial aconitase inactivation and cell death has 
been observed [12]. However, when considering exposure to exogenous $\mathrm{H}_{2} \mathrm{O}_{2}$, our study indicated protection from $\mathrm{H}_{2} \mathrm{O}_{2}$ action of the mitochondrial aconitase. This highlights that the topology is inversed between mitochondrial ROS mediated damage and $\mathrm{H}_{2} \mathrm{O}_{2}$ treatment. Possible explanation of the relative immunity of the mitochondrial matrix with regard to exogenous $\mathrm{H}_{2} \mathrm{O}_{2}$ could be diffusion limitations [17] or/and large excess in antioxidant defense, the latter expected to be also efficient against mitochondrial $\mathrm{H}_{2} \mathrm{O}_{2}$.

In conclusion, one may consider that mitochondria protect themselves and other cellular components from oxygen damage by three different means: avidly consuming oxygen, antioxidant defenses, and contribution to cellular bioenergetics to feed the renewal of damaged components. Mitochondrial impairment would in the first instance downgrade the above-mentioned protective roles. Further degradation would render mitochondria unable to check for their endogenous ROS and, worse, could increase their generation rate. Therefore, mitochondrial ROS release would not cause but rather highlight the decline in cellular bioenergetics and both would contribute cell death.

\section{Materials and Methods}

All cells were grown at $37^{\circ} \mathrm{C}$ with $5 \% \mathrm{CO}_{2}$ in media supplemented with $10 \%$ fetal bovine serum, $50 \mathrm{U} / \mathrm{mL}$ penicillin, and $50 \mu \mathrm{g} / \mathrm{mL}$ streptomycin. CHO-K1 cells (ATCC CCL-61) were grown in Ham's F-12 medium containing $10 \mathrm{mM}$ glucose, $1 \mathrm{mM}$ glutamax, and $1 \mathrm{mM}$ sodium pyruvate (Gibco 31765-027). Human lymphoblasts (HPB-All, Jurkat, DND, Molt4) were obtained from Françoise Pflumio (CEA, Fontenay aux Roses France) and were grown in RPMI medium (Gibco 61870-010). Human immortalized fibroblast cell lines were established by one of the co-authors (AL) and grown in DMEM with 1mM Glutamax 5mM glucose. For oxygen flux measurements the cells were resuspended in their culture medium after action of trypsin $0.05 \mathrm{~g} / \mathrm{L}$ in phosphate-buffered saline (PBS) containing $1 \mathrm{~g} / \mathrm{L}$ EDTA.

Oxygen concentration at $37^{\circ} \mathrm{C}$ was monitored with an Oroboros "O2k" (http://www.oroboros.at/ index.php?home). Oxygen consumption/production rate was calculated from oxygen concentration variation either with the DatLab software, which averaged rates over $80 \mathrm{~s}$, or by calculation of individual values between two successive measurements $(2 \mathrm{~s})$ when fast rates had to be considered (early phase of $\mathrm{H}_{2} \mathrm{O}_{2}$ consumption and $\mathrm{O}_{2}$ release). $\mathrm{H}_{2} \mathrm{O}_{2}$ solution was prepared each day of experiment from stock solution (Sigma ref. H1009). The concentration was checked by UV absorbance using the extinction coefficient at $240 \mathrm{~nm}$ of $46.3 \mathrm{~L} \times \mathrm{mol}^{-1} \times \mathrm{cm}^{-1}$.

To evaluate the impact of $\mathrm{H}_{2} \mathrm{O}_{2}$ on the aconitase to fumarase ratio $\mathrm{H}_{2} \mathrm{O}_{2}$ was added to $\mathrm{CHO}$ cells (approximately $2 \times 10 \mathrm{e} 6$ cells per $\mathrm{mL}$ ) incubated in the $\mathrm{O} 2 \mathrm{k} 37^{\circ} \mathrm{C}$ with stirring, and cell sampling was done 30 min after $\mathrm{H}_{2} \mathrm{O}_{2}$ addition. The aconitase and fumarase activities were measured in 96 well plates allowing measurement at $240 \mathrm{~nm}$ (Greiner Bio-One 675801) with a microplate reader equipped with two injectors (TECAN Infinite M200). Preparation of the plate was as follows: first $20 \mu \mathrm{L}$ of detergent solution in PBS was introduced in the wells, followed by $20 \mu \mathrm{L}$ of the cellular suspension in PBS, and, finally, by $50 \mu \mathrm{L}$ of Tris Buffer $0.5 \mathrm{M} \mathrm{pH}$ 7.4. In our study 36 wells were used simultaneously (12 samples in triplicates), and optimization led to 100,000 CHO cells per well with final concentrations of $0.01 \%$ digitonin and $0.05 \%$ Triton X100 to probe for cytosolic enzymes or cytosolic and mitochondrial enzymes, respectively. The plate was introduced in the plate reader to start the reading protocol for measurement of OD240 nm: (1) Shaking (15 s, 2 mm linear); (2) Four readings (each $60 \mathrm{~s}$ ) to evaluate the background and stability; (3) aconitase reaction with injection of isocitrate solution $120 \mathrm{mM}(25 \mu \mathrm{L}$ at $200 \mu \mathrm{L} / \mathrm{s}$ ), shaking as before, twelve readings (each $40 \mathrm{~s}$ ); (4) fumarase reaction with injection of malate $250 \mathrm{mM}$, rest of the procedure as before. Calculation of the aconitase to fumarase ratio was made with the assumption that the OD240 increase summed the rates of aconitase and fumarase reactions, which furthermore shared the same proportionality between OD increase and enzymatic reaction rate.

Author Contributions: Conceptualization, F.B.; methodology, A.L., C.R., and F.B.; investigation, C.R., C.V., and A.L.; writing - original draft preparation, C.R. and F.B.; writing-review and editing, F.B. and A.L.; funding acquisition, F.B. All authors have read and agreed to the published version of the manuscript. 
Funding: This research was funded by the Fondation ARC pour la Recherche sur le Cancer, grant number 20131200283.

Acknowledgments: The authors acknowledge the contribution of Mrs Sara Mrabet to experiments on sulfide genotoxicity and mitochondrial DNA qPCR.

Conflicts of Interest: The authors declare no conflict of interest.

\section{Abbreviations}

CHO Chinese Hamster Ovary

ROS Reactive Oxygen Species

MnSOD Manganese SuperOxide Dismutase (mitochondrial for of SOD)

EDTA Ethylene Diamine Tetra-acetic Acid

OD Optical Density

\section{Appendix A}

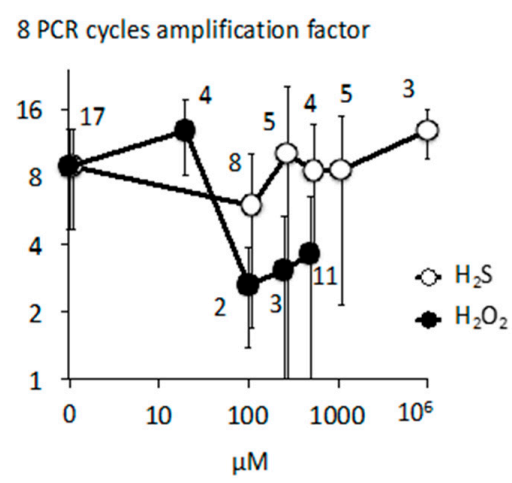

Figure A1. Quantitation of mitochodrial DNA damage: DNA was prepared from CHO cells exposed to $\mathrm{Na}_{2} \mathrm{~S}\left(\mathrm{H}_{2} \mathrm{~S}\right)$ or $\mathrm{H}_{2} \mathrm{O}_{2}$. qPCR of samples compared with that of a known amount of target sequence allowed absolute quantitation. This quantitative measurement was made either directly with $\mathrm{CHO}$ DNA preparation or after eight cycles of a long PCR amplifying a $8 \mathrm{~Kb}$ fragment of mitochondrial DNA (2976-11031) including the qPCR target sequence (6744-6918). Therefore, after the long PCR the theoretical amplification factor of the mtDNA target sequence is 64 times. The graph represents the experimental amplification factor ( $Y$ axis) when cells were exposed to increasing concentrations ( $X$ axis) of $\mathrm{H}_{2} \mathrm{~S}$ (empty symbols) or $\mathrm{H}_{2} \mathrm{O}_{2}$ (filled symbols). The number of experiments (independent treatment with $\mathrm{H}_{2} \mathrm{O}_{2}$ or $\mathrm{H}_{2} \mathrm{~S}$ ) is indicated. A log scale is used for both axes with following modifications: $\mathrm{H}_{2} \mathrm{~S}$ values are represented with $\mathrm{X}$ values $10 \%$ higher than reality, this allows distinction of error bars, the $10^{6}$ value $(1 \mathrm{M}) \mathrm{Na}_{2} \mathrm{~S}$ is represented as if $10^{4}$.

\section{Appendix B}

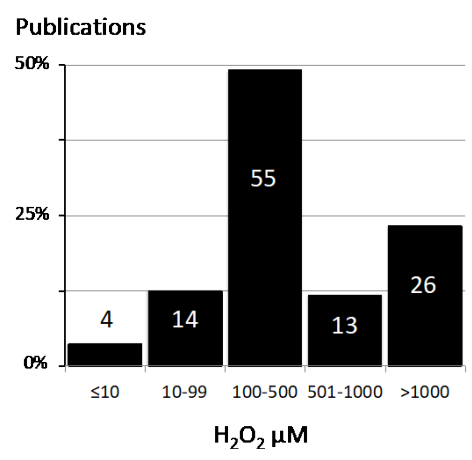

Figure A2. The histogram shows the percentage ( $Y$ axis) and the number of publications according to $\mathrm{H}_{2} \mathrm{O}_{2}$ concentrations. 
Table A1. The list hereafter indicates the PMID identifiers of the articles considered.

\begin{tabular}{|c|}
\hline $\mathrm{H}_{2} \mathrm{O}_{2} \leq 10 \mu \mathrm{M}$ \\
\hline 20572791 \\
\hline 29550333 \\
\hline 23044977 \\
\hline 9188618 \\
\hline $\mathrm{H}_{2} \mathrm{O}_{2}$ range $10-99 \mu \mathrm{M}$ \\
\hline 17925005 \\
\hline 19840190 \\
\hline 14981287 \\
\hline 12673362 \\
\hline 12832847 \\
\hline 15830107 \\
\hline 17451824 \\
\hline 29470430 \\
\hline 29208995 \\
\hline 10082315 \\
\hline 16331539 \\
\hline 18463796 \\
\hline 21293477 \\
\hline 26310930 \\
\hline $\mathrm{H}_{2} \mathrm{O}_{2}$ range $100-500 \mu \mathrm{M}$ \\
\hline 21284033 \\
\hline 12195838 \\
\hline 25383141 \\
\hline 31465957 \\
\hline 20072135 \\
\hline 28188272 \\
\hline 22885031 \\
\hline 25279550 \\
\hline 19151733 \\
\hline 12067712 \\
\hline 23484085 \\
\hline 14578137 \\
\hline 26861269 \\
\hline 27105496 \\
\hline 31562333 \\
\hline 26764141 \\
\hline 9012815 \\
\hline 22766155 \\
\hline 28204825 \\
\hline 29983082 \\
\hline 18501193 \\
\hline
\end{tabular}


Table A1. Cont.

\begin{tabular}{|c|}
\hline 23326372 \\
\hline 27582624 \\
\hline 31353362 \\
\hline 31683554 \\
\hline 17879239 \\
\hline 26225431 \\
\hline 29121706 \\
\hline 29386875 \\
\hline 18497977 \\
\hline 20847286 \\
\hline 23519197 \\
\hline 9551742 \\
\hline 22914987 \\
\hline 26991551 \\
\hline 29165341 \\
\hline 28977633 \\
\hline 20559505 \\
\hline 11905987 \\
\hline 18520066 \\
\hline 10409635 \\
\hline 14627202 \\
\hline 28122344 \\
\hline 26898812 \\
\hline 29431851 \\
\hline 27479053 \\
\hline 18003976 \\
\hline 31112588 \\
\hline 24695490 \\
\hline 11558568 \\
\hline 25381633 \\
\hline 28067784 \\
\hline 22796327 \\
\hline 15060142 \\
\hline 29386875 \\
\hline $\mathrm{H}_{2} \mathrm{O}_{2}$ range $501-1000 \mu \mathrm{M}$ \\
\hline 23349856 \\
\hline 25236744 \\
\hline 24642881 \\
\hline 9453543 \\
\hline 24634295 \\
\hline 20224152 \\
\hline 6292103 \\
\hline
\end{tabular}


Table A1. Cont.

\begin{tabular}{|c|}
\hline 30662338 \\
\hline 30662323 \\
\hline 15138265 \\
\hline 22580126 \\
\hline 16150148 \\
\hline 18954526 \\
\hline $\mathrm{H}_{2} \mathrm{O}_{2}$ range $>1000 \mu \mathrm{M}$ \\
\hline 10846797 \\
\hline 22302021 \\
\hline 8176261 \\
\hline 31783479 \\
\hline 30513827 \\
\hline 30366994 \\
\hline 16101127 \\
\hline 22542292 \\
\hline 23357941 \\
\hline 9422344 \\
\hline 8628669 \\
\hline 9735602 \\
\hline 26555819 \\
\hline 25528699 \\
\hline 21429293 \\
\hline 17085975 \\
\hline 20824890 \\
\hline 29351805 \\
\hline 22208537 \\
\hline 29661935 \\
\hline 14688260 \\
\hline 20566850 \\
\hline 16194237 \\
\hline 16936020 \\
\hline 21176282 \\
\hline 30634966 \\
\hline
\end{tabular}

\section{References}

1. Ward, J.F.; Evans, J.W.; Limoli, C.L.; Calabro-Jones, P.M. Radiation and hydrogen peroxide induced free radical damage to DNA. Br. J. Cancer Suppl. 1987, 8, 105-112. [PubMed]

2. Hirai, D.M.; Colburn, T.D.; Craig, J.C.; Hotta, K.; Kano, Y.; Musch, T.I.; Poole, D.C. Skeletal muscle interstitial $\mathrm{O}_{2}$ pressures: Bridging the gap between the capillary and myocyte. Microcirculation 2019, 26, e12497. [CrossRef] [PubMed] 
3. Gnaiger, E. Oxygen Conformance of Cellular Respiration: A perspective of mitochondrial physiology. In Hypoxia; Roach, R.C., Wagner, P.D., Hackett, P.H., Eds.; Advances in Experimental Medicine and Biology; Springer: Boston, MA, USA, 2003; Volume 543, pp. 39-55. ISBN 978-1-4613-4753-8.

4. Gnaiger, E.; Lassnig, B.; Kuznetsov, A.V.; Margreiter, R. Mitochondrial respiration in the low oxygen environment of the cell effect of ADP on oxygen kinetics. Biochim. Biophys. Acta BBA Bioenergy 1998, 1365, 249-254. [CrossRef]

5. Benamar, A.; Rolletschek, H.; Borisjuk, L.; Avelange-Macherel, M.-H.; Curien, G.; Mostefai, H.A.; Andriantsitohaina, R.; Macherel, D. Nitrite-nitric oxide control of mitochondrial respiration at the frontier of anoxia. Biochim. Biophys. Acta 2008, 1777, 1268-1275. [CrossRef] [PubMed]

6. Sepasi Tehrani, H.; Moosavi-Movahedi, A.A. Catalase and its mysteries. Prog. Biophys. Mol. Biol. 2018, 140, 5-12. [CrossRef] [PubMed]

7. Nandi, A.; Yan, L.-J.; Jana, C.K.; Das, N. Role of Catalase in Oxidative Stress- and Age-Associated Degenerative Diseases. Oxidative Med. Cell. Longev. 2019, 2019, 9613090. [CrossRef] [PubMed]

8. Shin, S.-K.; Cho, H.-W.; Song, S.-E.; Im, S.-S.; Bae, J.-H.; Song, D.-K. Oxidative stress resulting from the removal of endogenous catalase induces obesity by promoting hyperplasia and hypertrophy of white adipocytes. Redox Biol. 2020, 37, 101749. [CrossRef] [PubMed]

9. Attene-Ramos, M.S.; Wagner, E.D.; Gaskins, H.R.; Plewa, M.J. Hydrogen Sulfide Induces Direct Radical-Associated DNA Damage. Mol. Cancer Res. 2007, 5, 455-459. [CrossRef] [PubMed]

10. Yakes, F.M.; Van Houten, B. Mitochondrial DNA damage is more extensive and persists longer than nuclear DNA damage in human cells following oxidative stress. Proc. Natl. Acad. Sci. USA 1997, 94, 514-519. [CrossRef] [PubMed]

11. Beaumont, M.; Andriamihaja, M.; Lan, A.; Khodorova, N.; Audebert, M.; Blouin, J.-M.; Grauso, M.; Lancha, L.; Benetti, P.-H.; Benamouzig, R.; et al. Detrimental effects for colonocytes of an increased exposure to luminal hydrogen sulfide: The adaptive response. Free Radic. Biol. Med. 2016, 93, 155-164. [CrossRef] [PubMed]

12. Li, Q.-Y.; Pedersen, C.; Day, B.J.; Patel, M. Dependence of excitotoxic neurodegeneration on mitochondrial aconitase inactivation: Mitochondrial superoxide and excitotoxicity. J. Neurochem. 2001, 78, 746-755. [CrossRef]

13. Lagoutte, E.; Mimoun, S.; Andriamihaja, M.; Chaumontet, C.; Blachier, F.; Bouillaud, F. Oxidation of hydrogen sulfide remains a priority in mammalian cells and causes reverse electron transfer in colonocytes. Biochim. Biophys. Acta 2010, 1797, 1500-1511. [CrossRef]

14. Tochigi, M.; Inoue, T.; Suzuki-Karasaki, M.; Ochiai, T.; Ra, C.; Suzuki-Karasaki, Y. Hydrogen peroxide induces cell death in human TRAIL-resistant melanoma through intracellular superoxide generation. Int. J. Oncol. 2013, 42, 863-872. [CrossRef] [PubMed]

15. Biary, N.; Xie, C.; Kauffman, J.; Akar, F.G. Biophysical properties and functional consequences of reactive oxygen species (ROS)-induced ROS release in intact myocardium. J. Physiol. 2011, 589, 5167-5179. [CrossRef] [PubMed]

16. Xie, W.-H.; Ding, J.; Xie, X.-X.; Yang, X.-H.; Wu, X.-F.; Chen, Z.-X.; Guo, Q.-L.; Gao, W.-Y.; Wang, X.-Z.; $\mathrm{Li}, \mathrm{D}$. Hepatitis $\mathrm{B}$ virus $X$ protein promotes liver cell pyroptosis under oxidative stress through NLRP3 inflammasome activation. Inflamm. Res. Off. J. Eur. Histamine Res. Soc. Al 2020, 69, 683-696. [CrossRef] [PubMed]

17. Lismont, C.; Revenco, I.; Fransen, M. Peroxisomal Hydrogen Peroxide Metabolism and Signaling in Health and Disease. Int. J. Mol. Sci. 2019, 20, 3673. [CrossRef] [PubMed]

Publisher's Note: MDPI stays neutral with regard to jurisdictional claims in published maps and institutional affiliations.

(C) 2020 by the authors. Licensee MDPI, Basel, Switzerland. This article is an open access article distributed under the terms and conditions of the Creative Commons Attribution (CC BY) license (http://creativecommons.org/licenses/by/4.0/). 